\title{
Cytological features of uterine flushing in repeat breeder cows
}

\author{
S. ALAGAR, R. EZAKIAL NAPOLEAN ${ }^{1}$, M. SELVARAJU², \\ G. A. BALASUBRAMANIAM ${ }^{3}$ AND P. SELVARAJ ${ }^{4}$
}

\begin{abstract}
The present study examines the cytological features of uterine flushing in repeat breeder. On different days of interval the uterine flushing was carried out in repeat breeder cows with sterile normal saline solution $30 \mathrm{ml}$ on the day of selection (oestrus), 4, 8, and 12 . Uterine flushing was common for all the groups in this experiment and therapeutic protocol changed after uterine flushing day 12. The percentage of polymorphonuclear cells (PMNs) detected with endometrial cytology as an indicator of subclinical endometritis. Cytology samples were taken by low-volume flushing from 72 repeat breeder cows divided into six groups $(\mathrm{n}=12)$. In this study concluded that lows volume of uterine flushing by using normal saline at different day's interval might reduce the concentration of PMN. Uterine flushing in all experimental groups revealed decreased PMN cells in repeat breeder cows than at time of selection, therefore, uterine flushing technique was a useful and practical method to decrease the number of PMNs in the uterus of cattle.
\end{abstract}

Key words : Subclinical endometritis, Uterine flushing, Normal saline, PMN

How to cite this paper : Alagar, S., Napolean, R. Ezakial, Selvaraju, M., Balasubramaniam, G.A. and Selvaraj, P. (2017). Cytological features of uterine flushing in repeat breeder cows. Vet. Sci. Res. J., 8(1\&2) : 50-53, DOI : 10.15740/HAS/VSRJ/8.1and2/50-53.

Paper History : Received : 31.07.2017; Revised : 09.09.2017; Accepted : 24.09.2017 